\title{
AN INVESTIGATION INTO THE CONTENT OF TRACE ELEMENTS IN COW LIVERS ${ }^{2}{ }^{3}$ )
}

\author{
P. C. HART \\ Institute for Animal Husbandry Research T.N.O.
}

\begin{abstract}
SUMMARY
The content of the trace elements copper, zinc, manganese, molybdenum and cobalt was determined in the livers of 62 cows, half the number of which were treated for five weeks with VEVORON, a preparation containing methylthiouracil.
\end{abstract}

In the spring of 1950, under the supervision of the "Work Group Vevonon cow fattening experiment 1950", and with financial support of the N.V. KoninKLIJKE FABRIEKEN Wessanen at Wormerveer, experiments were made on cows at the stock-farm of the Firm of C. S. van BEUNingen at Maarsbergen in order to find out the effect produced by VEVORON (a preparation containing methylthiouracil) in the final fattening stage. The experimental group consisted of 31 animals, which for five weeks daily received 5 grammes of methylthiouracil contained in VEvoron, while the control-group, also consisting of 31 animals, received the same fodder, but without Vevoron.

As the producers of Vevoron tablets were of opinion that the most favourable effect of their preparation would be obtained on a ration poor in protein, care was taken that the cows were given but little hay, whereas the fattening fodder for the greater part consisted of ensilaged steamed potatoes and a meal mixture which was kept as poor as possible in protein.

Individual feeding was maintained wherever possible, on the understanding that the cows were each supplied with the steamed potatoes and the fattening fodder in wooden troughs, whereas the additional hay and straw was weighed per group and divided, at an estimate, within the group.

The daily ration per cow amounted to $3 \mathrm{~kg}$ hay, $12 \mathrm{~kg}$ ensilaged steamed potatoes, $6 \mathrm{~kg}$ meal mixture, and, besides, straw if desired. The meal mixture consisted of the following ingredients : rye-meal $27.91 \%$, barley-meal $20 \%$, oatmeal $16.67 \%$, maize-meal (corn-meal) $16.67 \%$, dried pulp $16.67 \%$, minerals $2.1 \%$. According to the calculation of the State Agricultural Research Station at Hoorn, the assimilated starch value was $7.1 \mathrm{~kg}$, that of the digestible raw protein $0.8 \mathrm{~kg}$, so that the animals received a ration poor in protein.

From the experimental results the conclusion could be drawn that, under the circumstances, VEvonon increases the living slaughter-weight, the slaughter-

1) The Work Group consisted of: Ir. H. VerschuYL, Adviser for Cattlebreeding in General Service, Chairman; Tr. Cuiper, Principal of the Butcher's Trade School at Utrecht; Dr. E. F. Drıon, Expert of the Statistical Department T.N.O.; Prof. Dr. J. J. Durvené DE WrT, Work Group Endocrinological Research Farm Animals T.N.O.; A. M. Frens, Director of the State Agricultural Research Station at Hoorn; Dr. P. C. Hart, Work Group Endocrinological Research Farm Animals T.N.O.; Prof. Dr. W. K. Hirschfeld, Professor of Zootechnics at the State University Utrecht; Prof. Dr. G. M. van DER Plank, ProfessorDirector of the Zootechnic Institute of the State University at Utrecht.

2) 73rd communication from the Institute for Animal Husbandry Research T.N.O.

3) Received for publication July 23, 1954 . 


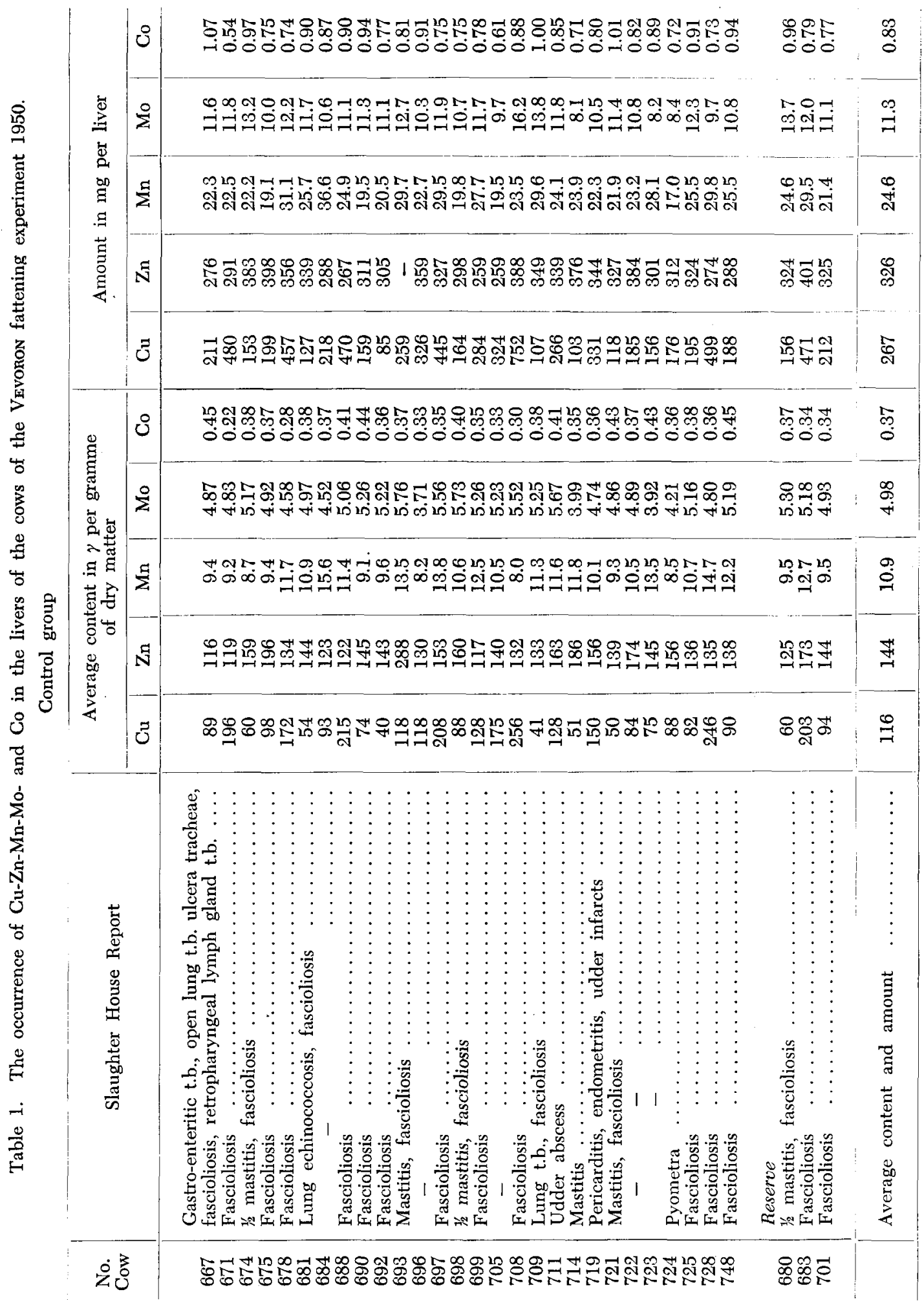




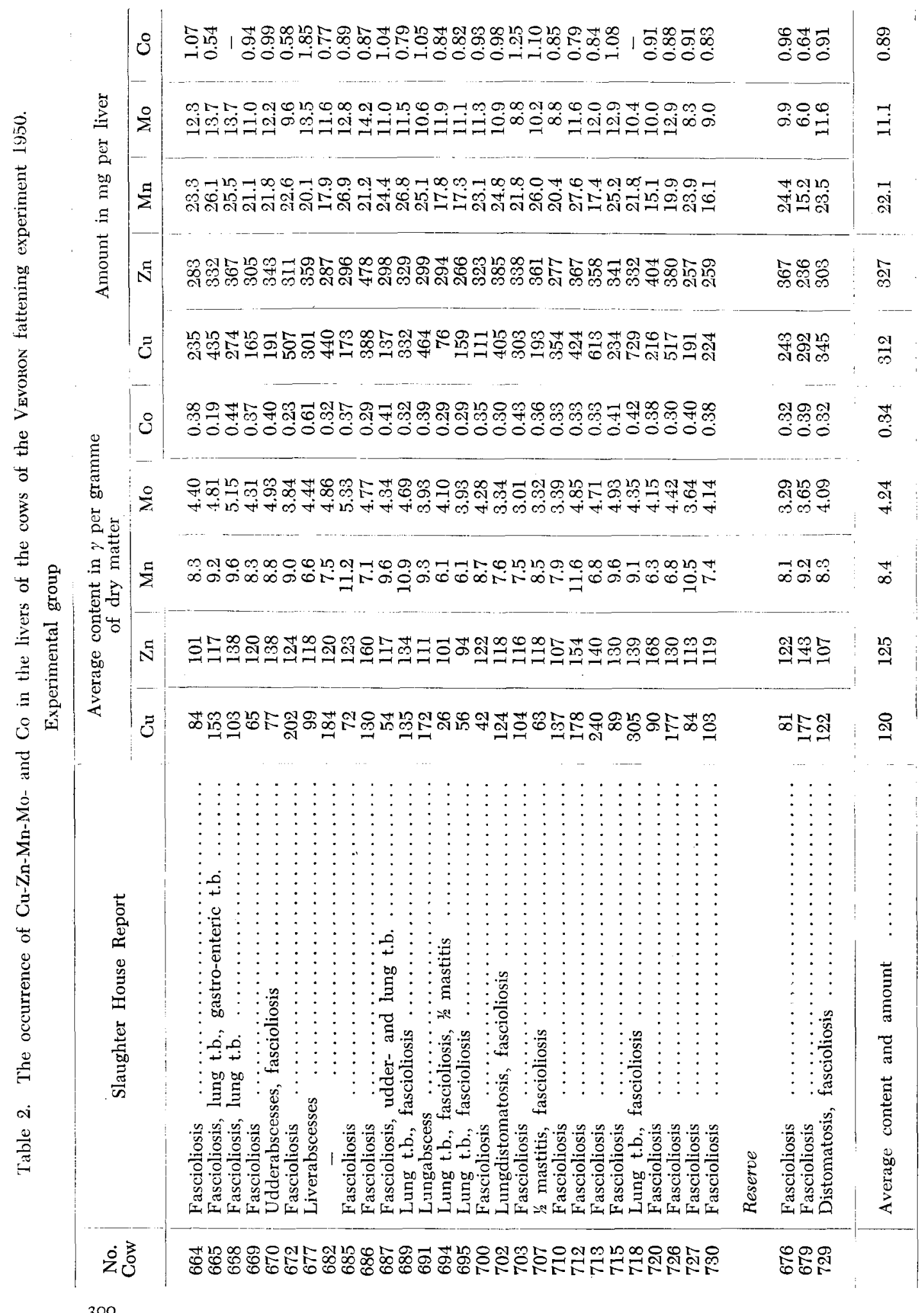


weight, as well as the weight of the liver. Effect of Vevonon on the amount of loose fat and on the water and fat content of the meat could not be demonstrated. Just as in previous experiments with antithyreoid substances like methylthiouracil for fattening purposes in cattle, some abnormal symptoms arose, among other things a marked filling of the first stomachs owing to a retarded gastro-enteric function, (FRENS, 1949). In this connection it seemed important to examine whether under the influence of this strumogenous substance, deviations from the normal content of trace elements might occur also. If this should be the case, there would be the possibility of preventing the detrimental accompanying phenomena mentioned by paying attention to the amount of trace elements in the fodder.

Since it is a well-known fact that the liver is a storage organ for most of the trace elements, and that with various morbid symptoms the contents of the different trace elements in the liver are abnormal, we confined ourselves to determining the content in the liver tissue.

The liver samples of about $1 \mathrm{~kg}$ obtained after slaughtering, were homogenized after having been kept in cold storage, then dried, and subjected to an investigation into the content of trace elements. Colorimetric or polarographic analysis methods were used. The results thus obtained, as well as the determination methods used have been reported in six publications concerning the elements molybdenum (VAN Esch and HART, 1953a), manganese (HART, 1953), copper (VAN Esch and Hart, 1953b), zinc (VAN Leeuwen and HaRT, 1952; HART, 1954a) and cobalt (HART, 1954b).

The analysis figures of the molybdenum and copper investigations which were not yet published, are presented in table 1 and 2 , together with those which bear upon the other three trace elements. This enables a mutual comparison of the contents of 5 trace elements in the livers of a relatively large number of cows, which grew up under the same circumstances for a period of more than five weeks. The cobalt content in the liver of the control animals on an average appeared to be $0.37 \gamma$ per gramme of dry matter. Molybdenum was found to amount to about thirteen times as much, averaging $4.98 \gamma$ per gramme of dry matter, whereas the element manganese was found to be more than twice as much as molybdenum (averaging $10.9 \gamma$ per gramme of dry matter). Zinc and copper were present in relatively large amounts, namely $144 \gamma \mathrm{Zn}$ and $116 \gamma \mathrm{Cu}$ per gramme of dry matter.

The content of zinc and molybdenum in the livers of the control animals appeared to be significantly higher than in the experimental animals; effect of Vevonon on the amount present in the liver - the Vevoron livers being very heavy - could not be demonstrated, however.

Whereas Vevoron appeared to have no effect on the occurrence of the elements copper and cobalt in the liver, the content of manganese as well as its amount in the livers of the control animals was higher than in the experimental group.

Between the "healthy" animals (no abnormalities at slaughtering except Fascioliosis) and the "sick" ones (with abnormalities at slaughtering, except Fascioliosis) there appeared to be a difference only with regard as to copper, because in the "healthy" animals the content as well as the amount of this element was significantly higher. 


\title{
LiteratuRe
}

Esch, G. J. vaN and P. C. HART: Landbouwk. Tijdschr. 65 (1953a) 195.

- -, - - : Landbouwk. Tijdschr. 65 (1953b) 738.

Frens, A. M. : Landbouwk. Tijdschr. 61 (1949) 916.

HART, P. C. : Tijdschrift voor Diergeneeskunde 78 (1953) 929.

- - : Tijdschrift voor Diergeneeskunde 79 (1954a) 91.

- - : Tijdschrift voor Diergeneeskunde 79 (1954b) 517.

Leeuwen, P. H. van and P. C. Hart : Chem. Weekbl. 48 (1952) 829.

\section{SOME OBSERVATIONS ON THE GENERATIVE DEVELOPMENT OF THE PEANUT ${ }^{1}$ )}

\author{
A. VAN ROSSEM and G. G. BOLHUIS
}

Laboratory of Tropical Agriculture, Agricultural University, Wageningen

\section{INTRODUCTION}

These observations were made on plants of the variety Schwarz 21, which variety belongs to the so-called Spanish group. It was selected at Buitenzorg (v. D. GIessen and Govers, 1939). The plants under study were grown in thermostat boxes under 12 hours' illumination from high-pressure mercury lamps (Philips HO 2000). The temperature was kept at $30^{\circ} \mathrm{C}$.

\section{Results}

Young plants showed simultaneous growth of the main axis and of cotyledonous buds and the first two axillar buds into stalks which are similar to the main axis. The development of the said buds seems to be at least as important as that of the main axis. These buds give always rise to leaves, in the axis of which are inflorescenses. Although the plants develop symmetrically, it was noted that one side is always somewhat more advanced in development. Flowering starts at the 23 rd day after sowing : the first flower always developing from the axillar buds of the first lateral stalks. At that moment the plants possesses 10-12 developed leaf packets with altogether $40-48$ leaflets. The greater part of the flowers are provided by the first lateral stalks.

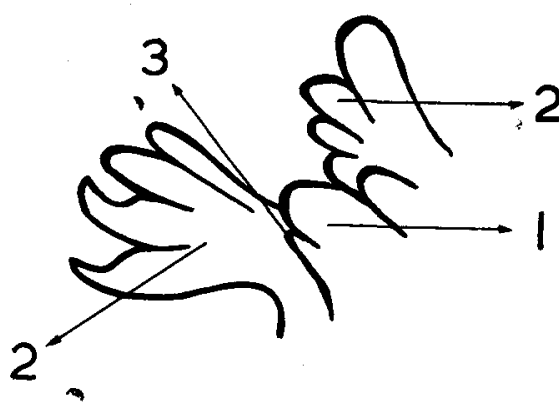

Fig. 1. Stem apex with vegetative CONE, 1. Growing point. 2. Leaf primordia in development. 3. New leaf primordium.

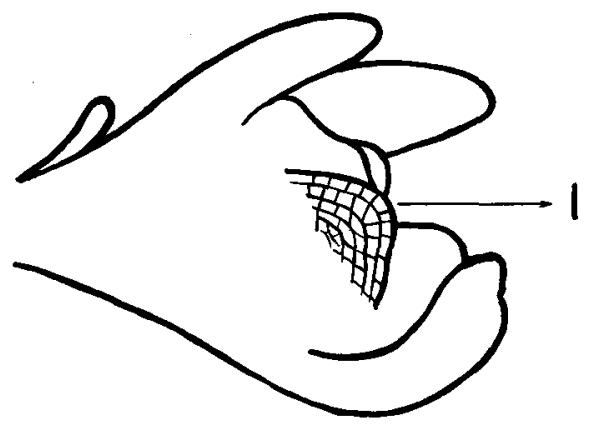

Fig. 2. AXILLARY BUD WITH FLOWER INITIATION AND TYPICAL "ClaW" ShaPE OF THE BRACTS. 1. Generative growing point.

1) Received for publication August 31, 1954. 